\title{
Chapter 13 \\ Securing Old-Age Pensions Across \\ Borders: Sudanese Transnational Families Across the Netherlands, the UK and Sudan
}

\author{
Ester Serra Mingot
}

\subsection{Introduction}

In recent years, the media, public opinion and political discourses have fed the idea that intra-European migrants are increasingly relying on the welfare states of their host EU country (Giulietti and Wahba 2012). Whereas some studies claim that the more-generous welfare states act as a migrant magnet (Borjas 1999; Enchautegui 1997), others do not find such clear-cut relation (Levine and Zimmerman 1999; Talleraas 2019). Yet, the so-called 'welfare migration' (Giulietti and Wahba 2012) or the likelihood of migrants moving to countries with more-generous welfare systems - has become a topic of political and public concern and has influenced important European political processes such as Brexit (Blauberger and Schmidt 2017).

Recently, a few qualitative studies have pointed to the 'onward movements' of some new migrant groups of refugee background - e.g. Somalis and Iranians - from countries with some of the most 'generous' welfare states such as the Netherlands, to the UK, where social welfare is less generous ${ }^{1}$ (Ahrens et al. 2016; Bang-Nielsen 2004; Haandrikman and Hassanen 2014). Many of these 'onward movers' first arrived in Europe as refugees and then moved to the UK after gaining citizenship of the first country of settlement, which grants them access to all the welfare benefits of that particular state, just like any other citizen. Yet, many decide to move to the UK as EU labour migrants, with all the restrictions this implies (see Broomfield

\footnotetext{
${ }^{1}$ In particular, when we look at the social-security domain of state-provided pensions, the generosity of the various EU states is quite different, so that a retired worker in the UK will receive a state pension (together with other benefits) worth around $29 \%$ of their previous earnings while, in the Netherlands, this goes up to 97\% (OECD 2017).
}

E. Serra Mingot $(\varangle)$

Bonn International Centre for Conversion (BICC), Bonn, Germany 
2014). Thus, from a welfare perspective, moving to the UK seems to be paradoxical at best.

In fact, despite the empirical evidence confirming these movements, this type of 'onward mobility' is still surprisingly poorly understood, leaving many questions unanswered. For example, little is actually known about these onward movers (e.g. age, marital status, gender), whether the movement stops there or what role the different welfare benefits - e.g. healthcare, unemployment or pensions - play in this move. Against this backdrop, this chapter explores the links between these 'onward movements' of EU citizens of refugee background and the particular socialprotection arrangements in the domain of old-age pensions. This contribution unravels the considerations underlying the decisions of Sudanese migrants when moving to certain places to address social-protection needs, specifically those related to old age. To do so, this chapter draws on the life stories of members of different Sudanese transnational families, spread across the Netherlands, the UK and Sudan. In so doing, it highlights the socio-cultural embeddedness of old-age provisions and the ways in which mobility and resources are combined to cover for oldage needs. Rather than looking at the individual migrant, this research takes the extended family as the main unit of analysis. It shows that the different mobility arrangements in which Sudanese migrants engage have the double intergenerational aim of providing for their elderly parents back home on the one hand and securing their own pension on the other.

The chapter contributes to the current debates on migration and social protection, questioning the some of the assumptions about so-called 'welfare migration' (Giulietti and Wahba 2012). As I show, despite the availability of formal socialprotection institutions in the first EU country of settlement, the informal circulation of resources within transnational families is deeply embedded in the practice of reciprocity and norms of social exchange rooted in the sending country. Analysing social protection from a transnational lens allows us to move away from nation states as the main 'containers of everything' (Serra Mingot and Mazzucato 2018). Welfare states thus become just one of the many resources that can be mobilised to provide generalised reciprocity and organise the old-age pensions of the different family members.

This chapter is based on data collected during 14 months of multi-sited and partly matched-sample ethnographic fieldwork with Sudanese migrants and their families across the Netherlands, the UK and Sudan (2015-2017). The Sudanese case is relevant for two main reasons. First, the Sudanese are a relatively small and new migrant group in Europe. This is important because new migrant groups face different migration and receiving contexts (Grillo and Mazzucato 2008) which might affect the ways in which they engage in the different social-protection practices. Second, in terms of legal status, the Sudanese are a highly heterogeneous group, including asylum-seekers, (un)documented migrants, refugees and citizens. This inevitably impacts on the rights of these different groups to access formal social protection.

The chapter is organised as follows. The next section provides a literature review on some of the current debates on migration and social protection, focusing on the 
specific aspect of old age and pensions. It then zooms in on what it means to grow old in the Sudanese context. After discussing the data presented in this chapter and the overall methodological aspects of this research, I present and address the two main analytical points - namely, the access and provision of pensions both for the migrants themselves and for their parents. The last section concludes by summarising the main findings and pointing out the importance of addressing transnational social protection (TSP) from the perspective of extended families, which allows them to move between multiple locations (beyond one sending and one receiving state) throughout different moments in time.

\subsection{Mobile Populations in Immobile Welfare Systems}

Nowadays, more and more people choose or are pushed to live across national borders, developing attachments and responsibilities in more than one nation state - for example, by caring for family members, earning their livelihoods or saving for their old age in different countries (Levitt et al. 2017). Yet, traditional welfare states and their national social-security systems have been created to cater for the needs of sedentary populations - citizens mainly living within the borders of the nation state. This becomes problematic for people with increasingly mobile lifestyles and responsibilities that span beyond a single country. For instance, when moving to another country, migrants risk losing any contribution made to the formal socialprotection system in the sending country, while often having to wait several years before having access, if at all, to formal social protection in the host country (Sabates-Wheeler 2009). Even when welfare provisions in the receiving country are accessible, migrants must often provide for their families 'back home' (Stark and Lucas 1988), who often lack access to formal social protection (if any) in their origin countries.

Transnational mobility has indeed obscured the clear-cut division between who should be socially protected by the state and who should not. It is not surprising, therefore, that, in recent decades, different aspects of migration and social protection have increasingly caught the attention of researchers and policy-makers. To date, research and policy have largely focused on the individual migrant's (lack of) access to the welfare state in the receiving countries in the Global North (SabatesWheeler and Koettl 2010; Sabates-Wheeler and Waite 2003; Van Ginneken 2013). This approach is problematic for two main reasons. On the one hand, it has perpetuated the idea that the Western industrialised countries - and by default their welfare systems - are the ultimate goal for any migrant. In so doing, they have largely neglected the role of other formal and informal social-protection institutions here and there - in both the receiving and the sending country. Although some of these studies acknowledge the important role of informal social protection, they mostly conceive of it in terms of filling the gaps of the formal system (Amuedo-Dorantes and Pozo 2006; Avato et al. 2010). Moreover, informal types of support are often addressed from a financial perspective, e.g. social networks in the receiving country 
providing newly arrived migrants with financial help, or remittances which migrants send to cover the needs of those back home (Sabates-Wheeler and Waite 2003). On the other hand, the focus on the individual migrant in the receiving country has overshadowed a crucial element in the social protection of mobile populations namely the role of migrants' families 'back home'. Indeed, even when welfare provisions in the receiving country are accessible, migrants are often responsible for providing for their families 'back home' (Stark and Lucas 1988). In fact, international migration does not necessarily sever the obligations between family members living apart (Baldassar et al. 2007). On the contrary, rather than an individual project of income maximisation in response to emergencies, migration is often a family livelihood strategy to diversify income sources, face up to socio-economic constraints and guarantee the wellbeing of the different family members (SabatesWheeler and Waite 2003; Stark and Lucas 1988). Yet, the increasingly restrictive and changing migration and welfare regulations lead many migrants to develop a series of strategies that encompass formal and informal resources from different institutions - often located in different countries - to cover not only for their own but also for their families' needs, now and in the future. Therefore, in order to understand such strategies, which combine formal and informal resources across borders, social protection is a more useful concept than social security or welfare, which are highly related to the support provided by the state. Social protection, on the other hand, is a broader concept as it includes different mechanisms of socialrisk management provided not only at a public but also at a private, community and market level (Avato et al. 2009). For the purpose of this chapter, transnational social protection (TSP) is understood as the combination of provisions provided by the state (the social-security system), the market, the third sector and family and social networks to protect individuals and families against declining living standards arising from a series of basic risks and needs (e.g. employment, healthcare, housing, old age or education) across the borders of two or more nation states (De Neubourg and Weigand 2000; Devereux and Sabates-Wheeler 2004; Levitt et al. 2017).

\subsubsection{Growing Old Across Borders}

One of the main dilemmas faced by adult migrants - as well as their elderly parents 'back home' - is how to cope with the experience of growing old across borders (Zickgraf 2017). From the perspective of the migrants in the receiving country, their access to state-provided pensions might be limited or not enough. For example, research has shown that some benefits, such as contributory pensions, do not deliver comfort in old age for many non-European labour migrants, due to the higher unemployment rates among this group and to the fact that many work in low- and unskilled positions, which deliver lower levels of pension (Dwyer and Papadimitriou 2006). A similar situation happens for people who enter a country as refugees over the age 
of 40 , since they often have to wait several years to find a job and, even if they do, are unlikely to secure a sufficient number of years' employment to access contributory-pension benefits (Dwyer and Papadimitriou 2006). In addition, many of these migrants might wish to spend their retirement years 'back home', in which case the pensions built up in the host country might be lost, as they are not always transferrable.

In fact, the challenges attached to the aging of mobile populations have caught the attention of researchers and policy-makers alike, who have increasingly looked at aspects related to the accessibility and portability of pensions (Dwyer and Papadimitriou 2006; Holzmann and Koettl 2011). In an attempt to make the current social-security systems more mobile, a series of bilateral agreements have emerged in recent years to enable the portability of certain social benefits, especially pensions and healthcare, from a receiving country to a migrant's country of origin (Holzmann and Koettl 2011). Such agreements, however, face multiple challenges and only exist between a small number of countries (Van Panhuys et al. 2017). Moreover, the extent to which migrants make use of the portability of state-provided pensions for old-age arrangements remains highly unclear. In fact, qualitative studies have shown that sometimes family-provided care - which might or might not be available in the migrant's receiving country, since family members might be living somewhere else - is prioritised over the benefits of strong welfare states (Liversage and Mirdal 2017; Serra Mingot and Mazzucato 2019). Yet informal care might not be easily accessible, since family members might be scattered across the borders of more than one nation state, facing mobility restrictions.

Besides the problems related to the access and portability of their own pensions, migrants - especially those from countries with weak welfare systems - are often responsible for providing for their aging parents back home. In fact, although the geographical distance - coupled with shifting migration regimes and financial possibilities - affects the intergenerational contract, the latter continues to shape how family should be 'done' (Krzyżowski and Mucha 2014) throughout the different life stages, especially during old age. Growing old across borders, therefore, is a complex multi-dimensional process that has an impact on the different family generations and is affected by multiple factors such as the legal status of the migrants, the more-or-less strict migration regimes of the different contexts in which the migrants and their families live, the gender of those giving and receiving care, the sociocultural norms of the sending and receiving contexts or the financial resources of the families (Serra Mingot 2020a).

In order to understand how migrants make sense of and arrange their pensions to cover for their old-age needs (for themselves as well as for their aging relatives), it is important to look beyond the individual migrant in the receiving country and investigate how other non-state-provided resources are accessed and circulated across national borders. In this regard, as this chapter shows, mobility is a crucial element through which to fulfil personal and family old-age arrangements. 


\subsubsection{Aging in Sudan}

If you manage to migrate to Europe, or America, life is better, but you have no money... Sometimes I wonder why I spent 37 years of my life in the KSA [Kingdom of Saudi Arabia] and did not go to another country...

These are the words of Youssif ${ }^{2}$ (67), the father of Salim (31), one of my respondents in the UK. I was very fortunate to meet Youssif in October 2016 because, by the time I conducted my fieldwork in Sudan, Youssif was in Egypt for healthcare reasons. He had undergone a cancer operation in Egypt, received chemotherapy in Saudi Arabia and continued with it in Egypt. He and his wife returned to Sudan just a couple of weeks before I left.

I met Youssif in their impressive three-storey house in a wealthy neighbourhood of Khartoum. He lived there with his wife, their younger son (who was about to start studying engineering) and their daughter with her three children (her husband worked in Iraq, so he mostly sent them money and visited them a few times a year). Since Salim and his older sister were working abroad, Youssif and his wife were renting two of the bedrooms in the house to some Chinese students. This was actually an important source of income during their old age. As we drank tea, Youssif told me about his experience as a labour migrant in Saudi Arabia. Like other Sudanese of his generation, Youssif had studied computer engineering in the UK, after which he had found a well-paid job in Saudi Arabia. When he could afford it, he married his wife, Munira, a Sudanese woman from Khartoum, who soon joined him abroad. His four children were born in Saudi Arabia but, when the eldest reached high-school age, his wife and children moved back to Sudan. This was (and still is) common practice among Sudanese labour migrants in the Gulf, since enrolling in Saudi universities is prohibitively expensive, thus encouraging families to return to Sudan or move somewhere else so that their children can attend university. Going to high school in Saudi Arabia, however, makes it more complicated for the children's future enrolment in Sudanese universities, entry to which depends on the score obtained in the Sudan School Certificate examination. Therefore, the most common solution for these families is for the wives and children to return to Sudan either to the house that the migrant has managed to build over the years to provide security in their old age or to the husband's family house - while the husbands remain abroad working and only visit once or twice a year.

Youssif's story illustrates one of the oldest and most common transnational family arrangements in Sudan. It points to different aspects around which old age is organised, since the role of the state is clearly absent. Sudan, however, has a national Pensions Fund - one of the oldest in Africa and the Middle East - which covers the pension for those aged 60 with at least 20 years of formal contributions, the survivor's pension and disability pensions (Social Security Administration 2007). Yet, despite the apparent availability of a formal pension system, my fieldwork interviews and observations elucidated that often the pension received (if any) could

\footnotetext{
${ }^{2}$ Pseudonyms are used to ensure the informants' anonymity.
} 
barely cover people's monthly food expenses, let alone their housing costs or medical emergencies. Therefore, those respondents who received a state pension needed additional support to survive, especially during old age.

In Sudan, therefore, the lack of a sufficient state-provided pension leaves most elderly people dependant on their children and extended families, who are fully responsible for their different social-protection needs (Adam and Yousif 2016; Gasim 2010; Mokomane 2013). Thus, as in other countries with weak or nonexistent welfare systems, the reciprocal circulation of care, money and other resources in Sudan within extended family networks are crucial for the family's social protection and reproduction (Akuei 2005; Mokomane 2013). To cover for old-age needs, people in Sudan would follow different strategies. Sometimes, as in the case of Salim and Youssif, the migrants' parents had worked in well-paid jobs in the Gulf, ${ }^{3}$ which had allowed them to save enough money to build a house. As Youssif's vignette shows, often many generations live in the grandparents' houses, so that financial and care duties are shared among family members. Renting some rooms or a small apartment within the family house compound was also a strategy followed by some families, which constituted an additional source of income to cover daily expenses. In some cases, besides building a house, the migrants' parents had set up a small business, which was now run by some younger relative, from whom they received a monthly revenue.

These arrangements, however, did not apply to all families. For many elderly people in Sudan the main source of financial security was the remittances sent by their children. Especially for healthcare emergencies, remittances are often the main - if not the only - resource. In recent years, the declining standards of public hospitals and the increasing privatisation of healthcare providers has resulted in prohibitively high healthcare costs that can only be afforded through remittances. Yet, the increase in the fees of medical services in Sudan has not seemed to translate into better services; on the contrary. Therefore, those who could afford it would often opt to receive treatment abroad, in countries such as Jordan, Egypt, Saudi Arabia, India, Thailand, Belgium or Germany. Affording healthcare abroad, however, requires the access and coordination of multiple resources, including money, care and housing. In the case of Youssif, for instance, Salim explained to me how his father's operation and treatment, which cost GBP 7000 (EUR 7800 approx.), was only possible through the money that mostly he and his siblings had put together. The financial costs of the operation were also lessened, thanks to the apartment that Youssif's brother owned in Cairo and where Youssif's wife could stay during the whole medical process.

The socio-cultural obligation to care for the elderly in the family does not only apply to the biological parents but also to other elderly relatives (e.g. aunts and uncles). This is because often the head of the family and his wife are obliged to provide for their own children, as well as their nephews, nieces and cousins (Adam

\footnotetext{
${ }^{3}$ People like Youssif, who work in the Gulf, are not entitled to receive any state pension even though, during their working years in the Gulf, they were bound to pay yearly taxes in Sudan.
} 
and Yousif 2016). Once these children become adults, they are in turn responsible for caring not only for their parents but also for grandparents, aunts and uncles. Children become the most available and reliable source of insurance during old age (Adam and Yousif 2016; Nauck and Klaus 2007). Investing in the children - in terms of education and family values - is of high importance for families (Serra Mingot and Mazzucato 2019; Zickgraf 2017). The role of children as the main oldage insurance - in terms of care and income - is deeply rooted in Sudan. Thus, one way of ensuring a comfortable old age is often envisaged as providing the family's children - e.g. one's own children, grandchildren, nieces or nephews - with the best possible education so that, in the future, they can have a highly paid job with which they can better support their parents (and other elderly relatives). Youssif's case is an example of how education is the main trigger for the family return to Sudan. Therefore, it was quite common to find humble families making enormous financial sacrifices to send their children to 'the best' schools that they could afford.

This understanding of a pension differs from the traditional Western and nationstate-centric perspective, where the pension or old-age insurance is mostly understood as the regular payments made by the state - sometimes, to different degrees, also the market - to cover the basic needs of its citizens at official retirement age. Yet, as illustrated above, in Sudan, like in many other developing countries, the idea of the 'pension' is much broader and fluid and involves a combination of resources, in which often the state is not the most relevant one (Mazzucato 2008; Serra Mingot 2018). Therefore, research on old age and pensions can no longer be limited to the

state, since growing old is shaped by migration and transnational practices (King et al. 2017). In order to understand how migrants make specific arrangements for their and their parents old age, it is important to analyse the 'pension' from a transnational lens, in order to be able to include elements of pensions here and there and to understand the role of such elements in shaping people's decisions to move.

\subsection{Data and Methods}

The data presented in this chapter are based on 14 months of ethnographic fieldwork conducted in 2015 and 2016 with Sudanese migrants in the Netherlands and the UK and their families back in Sudan. Multi-sited and partly matched-sample research was conducted using in-depth biographic interviews, informal conversations and participant observation with 43 respondents across the Netherlands and the UK and with 19 of the migrants' matched family members (mostly parents and siblings) in Sudan. Among the Sudanese respondents in the Netherlands and the UK, the majority were documented migrants, while only a few of them (in the Netherlands) had seen their asylum application rejected and become undocumented for several years, without access to any type of formal social protection (Serra Mingot and Mazzucato 2018). Among the documented, most of them had arrived in Europe through the asylum system and, after varying periods of time, had become either Dutch or British citizens. As such, they were entitled to welfare benefits like any other 
citizen, including old-age pensions. Several UK respondents had moved from the Netherlands and thus, in some cases, matched samples spanned the Netherlands, the UK and Sudan, giving us a wider view of how migrants navigate the different socialprotection systems. A matched-sample methodology is especially suited to studying old-age caregiving practices within transnational families, because it allows the researcher to sample individuals who are connected across different sites (Mazzucato 2009).

I conducted all the interviews and observations in English, Arabic or German, in familiar environments for the respondents - mostly in their homes. The interviews lasted between 2 and $4 \mathrm{~h}$, while participant observation ranged from attending events with the participants (e.g. concerts or family get-togethers) to spending a full week living with them in their homes. Most interviews were recorded through notetaking, respecting the respondents' wishes. The in-depth interviews and observations allowed me to construct the life histories of the different family members and to explore how old age was experienced by both the elderly and their adult children.

Research participants were recruited through different gatekeepers and snowball sampling with different starting points. The sample included refugees and (un)documented labour migrants, split between men and women of ages varying between the early 20s to the late 50s and including single men, married couples and divorced parents with children. The educational backgrounds of the respondents varied, though the majority had a tertiary educational degree from Sudan.

\subsection{Catering for Old-Age Needs Across Borders and Generations}

Both in the Netherlands and in the UK, most of my respondents had access to stateprovided pensions, since most of them had their respective Dutch or British citizenship, which they had obtained through the refugee system. Yet, for most of them, the idea of the state-provided old-age pension did not seem to be a major concern. Although many of my respondents in Europe were under 50 years old - and therefore they had more pressing issues to worry about than their own pension - two other factors should be considered. On the one hand, many of them had had to wait several years before obtaining refugee status and being allowed to work. For many, this long process had resulted in their being able to formally apply for a job for the first time in their 40s. In the current competitive labour market, many of these migrants struggled to find a job for years and, when they finally managed to, it was often in low paid and part-time positions. In the Netherlands, this was especially the case for women with children. Thus, they envisaged a rather low pension. On the other hand, most respondents, expressed their desire to grow old in Sudan, thus the expected returns of the welfare state in terms of pensions greatly lost their meaning in that neither Dutch nor British formal state-provided pensions can be transferred to Sudan. From this perspective, therefore, migrants for whom mobility is part of 
their lives and future plans might face difficulties when it comes to securing their formal pensions through geographically fixed institutions. It might, then, be safer and preferable to invest in and rely on assets that will stay and allow a high degree of flexibility, now and in the future - assets such as their children, who are the most common old-age insurance in Sudan. This reflects deeply rooted socio-cultural norms of the key role of family in informally catering for all old-age needs.

\subsubsection{Providing for One's Parents Pension}

As explained above, many elderly people in Sudan survive through the support of their children, be it in terms of money, care or both. Yet many of my respondents, especially those in the Netherlands, heavily depended on welfare benefits for many years, which they often coupled with informal jobs. Although this income was often enough for the migrant and their nuclear family (if any) here, many families were not able to send substantial monthly remittances to their family members back home. Moreover, recurrent unexpected and highly expensive healthcare emergencies - especially for elderly parents, aunts or uncles - put these migrants in the difficult situation of having a duty to help but not being financially able to do so. As previous research has shown, the highly regulated Dutch society, with its strong welfare state aimed at helping 'the weak, the poor and the helpless' (Ghorashi 2005, 181), has had the unintended consequence of leaving many people dependent on the state for many years. As studies have shown, however, minimum and temporary assistance, together with room for interaction in the new society, facilitates and speeds up the refugees' participation in the labour market (Ghorashi 2005). Besides the long asylum process, during which asylum-seekers are not allowed to work, once refugee status is given, people must usually go on re-training programmes, which might take years. As Hanadi (43) and Ensam (44), two of my Dutch-Sudanese female respondents in the UK told me, respectively:

In the Netherlands, even if you want to work in a supermarket, you have to go through one year of training.

[The Netherlands] was good for providing study but not for providing work.

Even in cases where these refugees had obtained their Masters degree in European universities, they also had to repeat all or a great part of these studies. I was particularly able to observe that this was the case when my respondents had obtained their certificate in a Eastern European country or in Russia. Due to the close links that Sudan had with communist countries in the past, several people had studied for their degree in countries such as Poland, Romania or Russia. While some respondents had had their Russian certificates almost fully validated in the UK, the Polish certificate of another respondent was rejected in the Netherlands. For many of these people, therefore, moving to the UK was seen as a faster way to access the labour market and, therefore, money with which to support their families back home. 
In some cases, being able to provide hands-on care for the parents was the main reason for leaving the Netherlands and moving to the UK. It is important to bear in mind, though, that, in past decades, migration regulations in the Netherlands and the UK have been in constant change. This affects different aspects of migration. For instance, the likelihood of being granted asylum or obtaining a visiting/medical visa for an elderly parent in the Netherlands or in the UK might vary greatly depending on the political agenda on migration at a specific moment in time. Yet, overall, obtaining visiting/medical visas seemed to be much more complicated in the Netherlands. As several respondents explained, they were not able to bring their parents to the Netherlands (INS 2020) for a visit due to the exorbitant financial requirements or other arrangements (e.g. living in a house of a minimum size to be able to host one or two people) they had to comply with. In comparison, the requirements in the UK are less strict.

This was the case for Ensam who, together with the lack of job opportunities in the Netherlands, moved to the UK primarily to be able to take care of her mother, who had been given a medical visa. In fact, the impossibility of bringing elderly parents from Sudan to the Netherlands due to the current immigration legislation was also a reason for some families to move to the UK. Sometimes, however, the process was quite complicated. This was the situation for one of my respondents in the UK, Hind (40). Hind was a Dutch-Sudanese citizen, who had arrived in the Netherlands as an asylum-seeker in the late 1990s. In 2005, however, her husband's mother became seriously ill in Sudan. Facing the restrictive migration regulations at the time and the resulting impossibility of bringing her mother-in-law to the Netherlands, Hind, her husband - also a Sudanese refugee - and two little children moved to Sudan to take care of her. Yet, after 2 years in Sudan, Hind realised that her children were struggling too much, in terms of both adaptation and educational achievements. Concerned for their future, the whole family moved back to Europe. Yet, instead of returning to the Netherlands, they moved to the UK, where the British regulations at the time allowed Hind to bring over her mother-in-law to receive the healthcare she needed, which had not been possible in the Netherlands.

\subsubsection{Arranging One's Own Pension}

When asked about their own old-age plans, many Sudanese respondents in Europe explained that providing their children with the best education possible was a priority and a form of old-age insurance. Indeed, throughout my fieldwork in different locations I observed how several respondents would invest a lot of resources to pay for their children's after-school lessons in order to have them obtain excellent grades and access 'the best' universities. As Mohamed (53), a British-Sudanese doctor in the UK who was unemployed as his certificate had not yet been validated, put it in a very straight-forward way: 'This is my insurance. I'm investing in them [his children] now'. 
Providing their children with the best education and future opportunities was also one of the main triggers of 'onward migration' from the Netherlands to the UK (Ahrens et al. 2016). In the Netherlands, depending on both the end-of-primaryeducation test results (when children are around 12 years old) and, especially, on the teacher's advice, students are transferred into different types of secondary education (OECD 2016). As some studies have shown (Klooster et al. n.d.; OECD 2016), such advice often underestimates and discriminates against students of migrant background, hindering their access to tertiary education. This was perceived by many respondents as discriminatory and many of the Dutch-Sudanese families I met in the UK had actually left the Netherlands, where they had citizenship, for this very reason. Hind, whom we met above, moved to the UK to take care of her mother-in-law; she explained that her second reason for moving there was that she felt, based on the experiences of other Dutch-Sudanese who had moved to the UK, that the educational opportunities for her children were better in the UK than in the Netherlands. Although Hind held warm memories of her life in the Netherlands and cherished many of aspects of the country - such as the feeling of safety or the quality of the housing - she was concerned that the Dutch educational system would not give her children the same opportunities as the system in the UK.

Yet, despite these investments for the children, several respondents were also aware and concerned that their children, born into Western welfare systems, would not have the same feeling of 'duty' to provide for their ageing parents in the future in the way that they, the parents, had envisaged. This concern was tackled in different ways, depending on the family possibilities. For example, some families would take their children to Sudan for long holiday periods and to take part in family events (e.g. weddings, funerals), where they could witness family duties and social norms. At other times, migrants' duty to care for their aging parents was combined with socialising their children into it. This was the approach taken by Hind who, despite the difficulties of moving to Sudan with two little children to take care of her sick and old mother-in-law, was happy that she had brought her children along. As she explained to me:

They learn that the parents are the first people they should take care of. As we learnt that from our parents, we taught that to our children, so they know how to help us and that they should take care of us.

In cases where face-to-face contact was not possible or was very sporadic, the children's socialisation took place digitally and was mostly implemented by their male relatives in Sudan or elsewhere, who would constantly call their grandchildren to discipline them on what to do and how to behave (Serra Mingot 2020b).

These examples show how the family and the intergenerational bonds of reciprocity among the different family members are the main pillar of old-age arrangements for transnational families, not only now but also in the future. That is, by showing their children how they take care of their own aging parents, these migrants are socialising them into the Sudanese socio-cultural norms of reciprocity. Such socialisation was, in fact, another reason that led some Dutch-Sudanese families to move to the UK. As one of my respondents explained, the Netherlands was often 
perceived as a country with too much freedom and with a relatively small Sudanese community. In the UK, however, the Sudanese community was bigger and thus the children were more exposed to - and also controlled by - Sudanese Muslim values. As one of my Dutch-Sudanese respondents in the UK told me: '[In the UK] everybody is controlling everybody'.

\subsection{Conclusions}

This chapter has explored the links between the 'onward movements' of SudaneseEuropean migrants and the particular social-protection arrangements in the domain of old-age pensions. Through different cases, I have analysed the complex mechanisms guiding the decision of Sudanese transnational families to access and circulate certain resources in order to cover for the different old-age needs, now and in the future. Such mechanisms have been rendered visible through a transnational perspective and a multi-sited matched-sample methodology, which allowed me to expand the unit of analysis from the individual migrant, as is often done in the social-protection literature, to extended family networks, whose members are scattered across different countries. This has shown that old-age needs take place simultaneously and across different generations (e.g. migrants providing for their elderly parents while making arrangements for their own old age). Moreover, it has highlighted the crucial role of mobility and the geographical distribution of individuals in orchestrating complex social-protection arrangements, such as old-age pensions.

The multi-sited matched-sample analysis has shown how decisions around oldage arrangements entail accessing and organising resources (in terms of people, finances and care) over multiple locations. Analysing social protection in general and old-age pensions in particular - through a transnational lens allows us to move away from nation states as the main 'containers of everything'. As the different cases presented in this chapter have shown, moving from the Netherlands to the UK is not based on assumptions of better state-provided welfare benefits. The analysis has shown that one of the main triggers of 'onward migration' is in fact the lack of possibilities for people to arrange their own and their families' social protection in the way that they envisage to be the best or the most appropriate. In taking into consideration the sending context and the sociocultural norms around old-age welfare protection, this chapter has provided evidence that these norms also travel and shape the ways in which old-age arrangements are made. Therefore, rather than talking about people moving to 'better welfare states', it seems more appropriate to talk about people moving to countries where specific resources are deemed better to cover for specific social-protection needs, such as education or possibilities for family-provided care in the UK. In fact, while the Dutch welfare state seems to be more generous, it is also more controlling, thus limiting people's capacity to work, bring over visiting relatives or follow a particular study path. In this regard the UK, although providing fewer welfare benefits, facilitates people's access to the labour market, access to the studies of their choice or the possibility to bring relatives over 
for a visit or medical treatment. This flexible character of the UK, however, has to be taken with caution. For instance, while access to the labour market (regular or irregular) is easier and less controlled, this can lead to the exploitation of people who are in need of money (Batnitzky and McDowell 2011; Bloch 2008; Dell'Olio 2004; McGregor 2007).

Looking at migration and social protection from the perspective of the extended family shows that decisions to move or stay in a specific place are based on the migrants' and their families' needs and how best to fulfil them. In fact, what the cases have shown is that, in the current context of geographically fixed welfare systems and restrictive migration regimes, people with an extensive history of mobility or with a widely geographically scattered family face difficulties when it comes to safeguarding their social-security benefits like formal pensions because, if they moving to another country, such social-security rights might not exist. Therefore, the old-age pension is not envisaged in terms of receiving a state pension but in terms of having one's own children as the main providers of income and care. Investing in people (e.g., children) and other universal and mobile assets (e.g. education) that can move across time and space is therefore often the preferred option for these transnational families.

Finally, what this contribution has shown is the importance of looking at TSP not only as a translocal process but also as a trans-temporal one. Indeed, what the different cases have shown is that family arrangements are orchestrated to provide not only for current old-age needs but also for those occurring in the future. From this perspective, therefore, the different generations become involved and have a specific role to fulfil, which might mean moving to certain places in order to access certain resources to cater for particular needs.

Acknowledgements This research was funded under Marie Curie Initial Training Networks (ITN) - Call identifier: FP7-PEOPLE-2013-ITN. It was conducted at the University of Maastricht and Aix Marseille. The author would like to thank the Centre d'études et de documentation économiques, juridiques et sociales (CEDEJ) in Khartoum for helping me conduct fieldwork in Sudan.

\section{References}

Adam, E. A. M., \& Yousif, H. M. (2016). Factors that influence the changing in family function in Sudan (Khartoum case study). International Journal of Scientific Research in Science and Technology, 2(3), 77-84.

Ahrens, J., Kelly, M., \& van Liempt, I. (2016). Free movement? The onward migration of EU citizens born in Somalia, Iran and Nigeria. Population, Space and Place, 22(1), 84-98.

Akuei, S. R. (2005). Sudan country study. Oxford. https://assets.publishing.service.gov.uk/ media/57a08c5c40f0b6497400117e/InformalRemittanceSudanStudy.pdf. Accessed 28 Sep 2020.

Amuedo-Dorantes, C., \& Pozo, S. (2006). Remittances as insurance: Evidence from Mexican immigrants. Journal of Population Economics, 19(2), 227-254. 
Avato, J., Koettl, J., \& Sabates-Wheeler, R. (2009). Definitions, good practices, and global estimates on the status of social protection for international migrants (Social protection discussion paper no. 909). Brighton: Institute of Development Studies.

Avato, J., Koettl, J., \& Sabates-Wheeler, R. (2010). Social security regimes, global estimates, and good practices: The status of social protection for international migrants. World Development, 38(4), 455-466.

Baldassar, L., Baldock, C. V., \& Wilding, R. (2007). Families caring across borders. New York: Palgrave Macmillan.

Bang-Nielsen, K. (2004). Next stop Britain: The influence of transnational networks on the secondary movement of Danish Somalis (Working paper no. 22). Brighton: University of Sussex, Sussex Centre for Migration Research.

Batnitzky, A., \& McDowell, L. (2011). Migration, nursing, institutional discrimination and emotional/affective labour: Ethnicity and labour stratification in the UK National Health Service. Social and Cultural Geography, 12(2), 181-201.

Blauberger, M., \& Schmidt, S. K. (2017). Free movement, the welfare state, and the European Union's over-constitutionalization: Administrating contradictions. Public Administration, 95(2), 437-449.

Bloch, A. (2008). Zimbabweans in Britain: Transnational activities and capabilities. Journal of Ethnic and Migration Studies, 34(2), 287-305.

Borjas, G. J. (1999). Immigration and welfare magnets. Journal of Labor Economics, 17(4), 607-637.

Broomfield, L. (2014). Migrant access to social security and healthcare: Policies and practices in the United Kingdom. London: The Home Office.

De Neubourg, C., \& Weigand, C. (2000). Social policy as social risk management. Innovation: The European Journal of Social Science Research, 13(4), 401-412.

Dell'Olio, F. (2004). Immigration and immigrant policy in Italy and the UK: Is housing policy a barrier to a common approach towards immigration in the EU? Journal of Ethnic and Migration Studies, 30(1), 107-128.

Devereux, S., \& Sabates-Wheeler, R. (2004). Transformative social protection (Working paper no. 232). Brighton: Institute of Development Studies.

Dwyer, P., \& Papadimitriou, D. (2006). The social security rights of older international migrants in the European Union. Journal of Ethnic and Migration Studies, 32(8), 1301-1319.

Enchautegui, M. E. (1997). Welfare payments and other determinants of female migration. Journal of Labor Economics, 15(3), 529-554.

Gasim, G. (2010). Reflecting on Sudan's higher education revolution under Al-Bashir's regime. Comparative and International Higher Education, 2(1), 50-53.

Ghorashi, H. (2005). Agents of change or passive victims: The impact of welfare states (the case of the Netherlands) on refugees. Journal of Refugee Studies, 18(2), 181-198.

Giulietti, C., \& Wahba, J. (2012). Welfare migration (IZA discussion paper no. 6450). Bonn: University of Bonn, Institute for Labor Economics.

Grillo, R., \& Mazzucato, V. (2008). Africa < > Europe: A double engagement. Journal of Ethnic and Migration Studies, 34(2), 175-198.

Haandrikman, K., \& Hassanen, S. (2014). Onward migration of African Europeans: Comparing attitudes to migration motives (Research report in demography no. 15). Stockholm: University of Stockholm.

Holzmann, R., \& Koettl, J. (2011). Portability of pension, health, and other social benefits: Facts, concepts, issues (IZA discussion paper no. 5715). Bonn: University of Bonn, Institute for Labor Economics.

INS. (2020). Holiday and family visits. Immigration and naturalisation service. Amsterdam: Ministry of Justice and Security. https://ind.nl/en/short-stay/Pages/Holiday-and-family-visit. aspx. Accessed 18 Sep 2020. 
King, R., Lulle, A., Sampaio, D., \& Vullnetari, J. (2017). Unpacking the ageing-migration nexus and challenging the vulnerability trope. Journal of Ethnic and Migration Studies, 43(2), 182-198.

Klooster, E., Kocak, S., \& Day, M. (n.d.). Mbo En de Stagemarkt: Wat Is de Rol van Discriminatie? Utrecht: Kennisplatform Integratie \& Samenleving. https://www.kis.nl/sites/default/files/bestanden/Publicaties/mbo-stagemarkt-rol-van-discriminatie.pdf. Accessed 18 Sep 2020.

Krzyżowski, Ł., \& Mucha, J. (2014). Transnational caregiving in turbulent times: Polish migrants in Iceland and their elderly parents in Poland. International Sociology, 29(1), 22-37.

Levine, P. B., \& Zimmerman, D. J. (1999). An empirical analysis of the welfare magnet debate using the NLSY. Journal of Population Economics, 12, 391-409.

Levitt, P., Lloyd, C., Mueller, A., \& Viterna, J. (2017). Transnational social protection: Setting the agenda. Oxford Development Studies, 45(1), 2-19.

Liversage, A., \& Mirdal, G. M. (2017). Growing old in exile: A longitudinal study of migrant women from Turkey. Journal of Ethnic and Migration Studies, 43(2), 287-302.

Mazzucato, V. (2008). Transnational reciprocity: Ghanaian migrants and the care of their parents back home. In E. Alber, S. van der Geest, \& S. Reynolds Whyte (Eds.), Generations in Africa: Connections and conflicts (pp. 91-109). Munster: LIT Verlag Münster.

Mazzucato, V. (2009). Bridging boundaries with a transnational research approach: A simultaneous matched sample methodology. In M. A. Falzon (Ed.), Multi-sited ethnography (pp. 1-31). Farnham: Ashgate.

McGregor, J. (2007). Joining the BBC (British bottom cleaners): Zimbabwean migrants and the UK care industry. Journal of Ethnic and Migration Studies, 33(5), 801-824.

Mokomane, Z. (2013). Social protection as a mechanism for family protection in sub-Saharan Africa. International Journal of Social Welfare, 22(3), 248-259.

Nauck, B., \& Klaus, D. (2007). The varying value of children: Empirical results from eleven societies in Asia, Africa and Europe. Current Sociology, 55(4), 487-503.

OECD. (2016). The Netherlands 2016: Foundations for the future. Paris: OECD Publishing.

OECD. (2017). Pensions at a glance 2017: OECD and G20 indicators. Paris: OECD Publishing.

Sabates-Wheeler, R. (2009). Social security for migrants: Trends, best practice and ways forward (ISSA working paper no. 12). Geneva: International Social Security Association.

Sabates-Wheeler, R., \& Koettl, J. (2010). Social protection for migrants: The challenges of delivery in the context of changing migration flows. International Social Security Review, 63(3-4), $115-144$.

Sabates-Wheeler, R., \& Waite, M. (2003). Migration and social protection: A concept paper (Working paper no. T2). Brighton: Institute for Development Studies.

Serra Mingot, E. (2018). Protecting across borders. Sudanese families across the Netherlands, the UK and Sudan. Maastricht: University of Maastricht, $\mathrm{PhD}$ thesis published by Datawyse/ Universitaire Pers Maastricht.

Serra Mingot, E. (2020a). Ageing across borders: The role of Sudanese elderly parents in the process of kin and home making within transnational families. In B. Pasveer, O. Synnes, \& I. Moser (Eds.), Ways of home making in care for later life. London: Palgrave Macmillan.

Serra Mingot, E. (2020b). The gendered burden of transnational care-receiving: Sudanese families across the Netherlands, the UK and Sudan. Gender, Place and Culture, 27(4), 546-567.

Serra Mingot, E., \& Mazzucato, V. (2018). Providing social protection to mobile populations: Symbiotic relationships between migrants and welfare institutions. Journal of Ethnic and Migration Studies, 44(13), 2127-2143.

Serra Mingot, E., \& Mazzucato, V. (2019). Moving for a better welfare? The case of transnational Sudanese families. Global Networks, 19(2), 139-157.

Social Security Administration. (2007). Social security programs throughout the world: Africa, 2007. Washington: Social Security Administration.

Stark, O., \& Lucas, R. (1988). Migration, remittances and the family. Economic Development and Cultural Change, 36(3), 465-481. 
Talleraas, C. (2019). Reconciling transnational mobility and national social security: What say the welfare state bureaucrats? Journal of Ethnic and Migration Studies, 45(1), 151-169.

Van Ginneken, W. (2013). Social protection for migrant workers: National and international policy challenges. European Journal of Social Security, 15(2), 209-221.

Van Panhuys, C., Kazi-Aoul, S., \& Binette, G. (2017). Migrant access to social protection under bilateral labour agreements: A review of 120 countries and nine bilateral agreements (Working paper no. 994955792602676). Geneva: International Labour Organization.

Zickgraf, C. (2017). Transnational ageing and the 'zero generation': The role of Moroccan migrants' parents in care circulation. Journal of Ethnic and Migration Studies, 43(2), 321-337.

Open Access This chapter is licensed under the terms of the Creative Commons Attribution 4.0 International License (http://creativecommons.org/licenses/by/4.0/), which permits use, sharing, adaptation, distribution and reproduction in any medium or format, as long as you give appropriate credit to the original author(s) and the source, provide a link to the Creative Commons license and indicate if changes were made.

The images or other third party material in this chapter are included in the chapter's Creative Commons license, unless indicated otherwise in a credit line to the material. If material is not included in the chapter's Creative Commons license and your intended use is not permitted by statutory regulation or exceeds the permitted use, you will need to obtain permission directly from the copyright holder. 